\title{
ITGB7 Gene
}

National Cancer Institute

\section{Source}

National Cancer Institute. IT GB7 Gene. NCI Thesaurus. Code C104251.

This gene plays a role in both cell-matrix adhesion and integrin-mediated signaling. 